\title{
The influence of cooperative relations of small businesses on environmental protection intensity
}

\author{
Sonia Benito-Hernández ${ }^{1}$ \\ Manuel Platero-Jaime ${ }^{2}$ \\ Pablo Esteban Sánchez ${ }^{3}$
}

\footnotetext{
${ }^{1}$ Corresponding autor: E-mail addresses: sonia.benito@upm.es. Universidad Politécnica de Madrid. Economics Department. Tel. +34 913365419

2* Universidad Europea de Madrid, Business Economics Department.+34 9121152 24, E-mail addresses: manuel.platero@uem.es

${ }^{3}$ Universidad Europea de Madrid, Business Economics Department.+34 9121152 24, E-mail addresses: estebanpab@gmail.com
} 


\title{
The influence of cooperative relations of small businesses on environmental protection intensity
}

\begin{abstract}
This study examines the relationship between one of the most important policies of social responsibility in manufacturing: the protection of the environment and cooperative business relations in small businesses (fewer than 50 employees). For this, we performed a literature review and an empirical study of 930 small manufacturing firms in Spain. Results indicate that small businesses that maintain and improve their cooperative relations through business networking with universities, competitors, suppliers and customers spend more on environmental protection than those which do not. The managerial, practical, research and policy implications of the obtained research findings are discussed.
\end{abstract}

Keywords: Small Business, Environmental Protection, Business Cooperation, External Relationships.

JEL: M210, M140, L600, L250.

\section{Introduction}

The current socio-economic context, characterized by the disappearance of trade barriers between countries and the implementation of increasingly large and homogeneous economic systems, has thrust companies into an increasingly more open and less protected market (Benito-Hernández et al., 2012). Although this situation favors business innovation and competitiveness (Platero-Jaime, 2014), it also causes the exponential growth of problems related to the bio-natural environment, such as global warming, air/water pollution and land degradation (Bagur-Femenias, 2013).

In this context, global concerns about the depletion of natural resources, climate change, energy security, the scarcity of resources and biodiversity loss are becoming increasingly more crucial in the business reality (Hawken et al. 1999; Wilson 2002; Keijzers 2005; Rațiu and Mortan, 2014). Increasing environmental awareness and the growing demand for environmental products and services has caused an upsurge of interest in environmental sustainability (popularly known as "going green") among corporate managers and entrepreneurs (Schmitter, 2012; Rațiu and Mortan, 2014).

Consequently, an increasing number of firms have begun engaging in environmentally friendly business practices (Hawken et al. 1999; Wilson 2002; Keijzers 2005; Leonidou et al., 2013; Rațiu and Mortan, 2014). For instance, several businesses have 
implemented sustainable practices, such as recycling, water conservation and energyefficient management systems (Rao et al., 2009; Herren and Hadley, 2010). Hence, firms are encouraged to develop and nurture their environmental sustainability orientation (ESO).

In this sense, a popular view is that business firms are expected to have a triple bottom line approach (Elkington, 1994) in the conduct of business (Luken and Stares, 2005; Kleine and Hauff, 2009) to become sustainable in the long term. According to Banjo Roxas and Doren Chadee (2012), the triple bottom line approach suggests that firms need to incorporate not only economic gains but also environmental dimensions in their overall strategic agenda (Masurel, 2007; Zwetsloot and van Marrewijk, 2004).

Furthermore, Oxborrow and Brindley (2013) state how proactive businesses can achieve first-mover benefits by adopting more sustainable practices, which in turn creates a competitive advantage that is hard for competitors to copy (Markley and Davis, 2007). In this respect, some researchers have demonstrated how cooperation and corporate social responsibility (CSR) could help companies to achieve eco-advantages (Esty and Winston, 2009) and overcome the current crisis (Fernández-Feijóo-Souto, 2009; BenitoHernández et al., 2011; Benito-Hernández and Platero-Jaime, 2012). Thus, the adoption of environmental management systems (EMS) as frameworks for integrating corporate environmental protection policies, programs and practices is growing among both domestic and multinational companies around the world. (Morrow, Rondinelli, 2002).

Consequently, leading companies that meet customer and environmental needs will be able to build product platforms and loyalty based on environmental issues, adding new values and innovations and developing the reputation of a trusted eco-brand (Lynne, 2008). Some examples might include Patagonia, Nike and Starbucks, Toyota, Ikea and, perhaps more controversially, BP (Esty and Winston, 2009).

In recent decades, the number of scholarly contributions to environmental business research has increased tremendously (Bagur-Femenias et al., 2013). However, most of them have focused on large manufacturing firms, with small and medium-sized enterprises (SMEs) receiving relatively less attention (Clemens 2006; Ostrom et al. 2010).

According to Banjo Roxas and Doren Chadee (2012), there is a plethora of studies on how large and multinational firms demonstrate their commitment to the triple bottom line approach to sustainability in business. However, little is known about how small firms demonstrate their strategic orientation towards environmental sustainability (Perrini et al., 2007; Dangelico and Pujari, 2010; Lee and Klassen, 2008; Martin-Tapia et al., 2010; Kuckertz and Wagner, 2010).

As SMEs are not simply smaller versions of their larger counterparts (Shuman and Seeger, 1986; Tilley, 2000; Battisti and Perry, 2011), different considerations and 
approaches may be needed to deal with social and environmental issues. As pointed out by Banjo Roxas and Doren Chadee (2012), to date no attempts have been made to empirically measure the ES of small firms in a developing country setting.

Tilley (1999) identified a significant gap in the literature regarding the response of small firms to the environmental challenge, especially literature based on analytical enquiry. Since then, the growing recognition that SMEs have a significant aggregate influence on the environment (Gadenne et al. 2009) has led to studies on the environmental management practices of smaller firms (e.g., Fuller and Tian 2006; Perrini 2006; Perrini et al. 2007; Gadenne et al. 2009; Lynch-Wood et al. 2009). However, relatively few papers have explored this issue (Oxborrow and Brindley, 2013).

According to Uhlaner, et al. (2012), only a few studies rely on inferential statistics and large random samples of firms (including SMEs) to test hypotheses (e.g. Russo and Fouts, 1997: Perrini et al., 2007; Brand and Dam 2009; Gadenne et al. 2009). This paper uses a large-scale sample and statistical tools to enhance our knowledge of the different business factors which influence the environmental management practices of Spanish SMEs. Specifically, the aim of our work is to study the relationship between one of the most important social responsibility policies in manufacturing: environmental protection and cooperative business relations in the case of small businesses (fewer than 50 employees).

In particular, the research question addressed is: Are certain aspects of the organizational context of small Spanish enterprises (business cooperation, quality management, range of operation, company size, innovativeness and external relationship) associated with greater environmental expenditure?

In the next section, we provide a detailed discussion of the different variables analyzed and environmental management practices, as well as a brief overview of SMEs in Spain and the evolution of CSR and environmental sustainability as concepts. We then briefly summarize the theory of planned behavior in the theoretical framework section, and present our hypotheses and their rationale. The method section explains our approaches to data collection, measurement and analysis. The remaining sections cover the results, interpretation of results, limitations of our study, directions for future research, and finally, the conclusions and practical implications. 


\section{Literature Review}

\subsection{The importance of sustainable development discussion}

In recent decades, the various economic agents have become more concerned about the problems related to environmental degradation. This growing concern is due to global warming that is occurring partly through $\mathrm{CO}_{2}$ emissions, in addition to air pollution, water pollution and land degradation. As a result, an ever increasing number of companies have begun to adopt more environmentally friendly business practices (Leonidou et al. 2013). These practices are not only carried out by the company internally, by hiring managers or encouraging socially responsible green activities (Aragón-Correa and Rubio-López 2007; González-Benito and González-Benito 2005; Miles and Covin 2000), but they are also imposed on the company by external forces such as environmental regulations and the preferences of responsible consumers. This motivates the study of environmental issues, although in many different directions (Leonidou and Leonidou 2011).

In the $70 \mathrm{~s}$ and $80 \mathrm{~s}$, scientific papers began to be published on sustainable development and presented the idea of a "dying earth". This provoked debate on the role of society in addressing these problems. So in 1987, the World Commission on Environment and Development (WCED), also known as the Brundtland Commission defined sustainable development as: "seeking to meet the needs and aspirations of the present, without compromising the ability to meet those of the future" (Brundtland Commission, 1987).

The term sustainable development, like the terms innovation or corporate sustainability, has many meanings. Among the definitions of sustainable development is the one by Maddox (2000): 'With the environment doing something to closing production chains and having no negative impact whatsoever'. The concept of environmental sustainability has become increasingly important for the business sector, requiring the reconciliation of traditional conflicts between economic imperatives and environmental goals. This has transformed business activities, making them less harmful to the environment (Tilley and Fuller, 2000). Thus, according to Roxas et al. (2009), their aggregate business activities may have a potentially negative impact on the environment as they consume energy and produce wastes and other by-products from their core business operations. Therefore, sustainable development and sustainability have become important concepts in business literature (Evans and Sawyer, 2010; Bos-Brouwers, 2010).

\subsection{Corporate Sustainability and Small Businesses}

The concept of corporate sustainability (CS) includes the notions of: creating a competitive advantage, profitability, increased pressure of the parties, compliance with legal requirements, concerns about corporate social responsibility, improved internal 
organization and the performance of environmental activities (Ranganathan and Willis, 1999; daily and Walker, 2000; Van Marrewijk and Werre, 2002; Dunphy et al., 2003). CS currently forms part of the debate on how companies can carry out their corporate responsibility in the midst of environmental problems at the global scale (Melnyk et al., 2001; Sharma et al., 2010; Kleine and Hauff, 2009; Dangelico and Pujari, 2010; Agarwala, 1993).

In fact, several authors have discussed the different phases of sustainability (Dobers and Wolff, 2000; Jordan and Fortin, 2002; Dunphy et al., 2003). For instance, Keijzers (2002, 2005) stated that there are three phases and fundamental motivations for corporate sustainability: (1) sanitize - compliance-driven clean-up or health and safety efforts of companies (2) control - eco-efficiency-driven adequate social or environmental management (3) integration - all value creation by integrating ecological and social issues into all business decisions.

However, while many large multinational companies have implemented sustainability measures given their abundant resources, little is known about the nature and extent of environmental sustainability (ES) of small businesses. A company's size seems to determine its organizational capacity to implement appropriate environmental initiatives and its environmental performance (Elsayed, 2006).

A company's size is normally representative of the nature and amount of resources available to the company (Bonaccorsi, 1992; Penrose and Pitelis, 2009; Lepoutre and Heene, 2006). Smaller companies are generally associated with scarcer resources, a smaller scale of operations and lower visibility compared to large companies (Udayasankar, 2007). Martin-Tapia et al. (2010) found a positive relationship between a company's size and the development of the environmental strategies in a study of 123 export SMEs in Spain. Similarly, in a study of 3,680 Italian companies Perrini et al. (2007) found that a company's size influences the nature and extent of corporate behavior towards social responsibility.

Sustainable practices differ between small and large firms, given the structural and cultural differences as well as difference in resources between these two types of companies (Bos-Brouwers, 2010). It is important, therefore, to study how small businesses and SMEs exert their ES given their unique organizational characteristics.

SMEs have some features that make it easier for them to implement and develop activities involving environmental responsibility. For instance, they have informal forms of communication and flexible organizational structures (Bos-Brouwers, 2009) which favor a less bureaucratic management of environmental and social issues.

However, the potential disadvantages faced by SMEs include certain challenges such as innovation in the context of sustainable enterprises (the Br1'o and Junquera, 2003), its application in SMEs (Jenkins, 2006; Roxas 2009; Luetkenhorst, 2004; Russo and 
Tencati, 2009; Sweeney, 2007) and resource constraints like lack of time, personnel, knowledge and financial capital (Azzone and Noci, 1998; Bos-Brouwers 2009; the Brío and Junquera, 2003; Spence, 1999). This may lead the company to make fewer investments and subsequently implement fewer eco-innovations (Noci and Verganti, 1999; Rennings, 2000). In general, SMEs incorporate eco-innovation to varying degrees, as these companies follow a strategy based on reactive or anticipatory innovation (Noci and Verganti, 1999).

Some authors have described five fundamental aspects that differentiate small businesses from big businesses: access to resources, decision-making processes, values, policies and sensitivity to brand reputation and image. These factors also help to explain differences in their environmental practices (see Cambra- Fierro et al. 2008; Williamson et al 2006). These differences mean that SMEs cannot simply adapt the practices established for large corporations (Jenkins 2004; Williamson et al 2006).

However, there are studies that indicate otherwise. A recent study by Sinha and Akoorie (2010) suggests that smaller companies are now in a better position to have an intense ES due to their inherent flexibility and adaptability. These qualities allow these smaller companies to respond to environmental pressures relatively quickly (Sinha and Akoorie, 2010).

Similarly, a survey of 108 SMEs in the automotive repair industry in Spain showed that SMEs have the ability to implement several types of environmental strategies despite their limited resources (Aragón-Correa et al., 2008). While these sustainability measures may not be as important, formal or sophisticated as the management systems for environmental sustainability implemented by large companies, they tend to complement the nature and scale of business operations of small businesses (Sinha and Akoorie, 2010).

Table 1 shows the main differences between small and large firms and the advantages and disadvantages that microenterprises may have when adopting CSR policies, including environmental liabilities.

(Table 1)

The limited empirical evidence suggests that conventional resources such as finances are one of the main determinants of the adoption and intensification of ES in small businesses. The inherent inability or difficulty of small businesses to adopt or implement sustainable environmental programs and activities can be attributed in great part to their limited or lack of resources (Del Brio and Junquera, 2003; Jamali et al , 2009; Holland and Gibbon, 1997; Sinha and Akoorie, 2010). 
The resource-based view of the firm (Barney, 1991; Wernerfelt, 1984) suggests that the strategic orientation and management of a company oriented towards developing a competitive advantage and better business performance will greatly depend on the nature of the resources the company has. This theory also suggests that a company can carry out a specific strategy like ES if it has enough resources to support the activities associated with this strategic orientation (Galbreath, 2005).

The adoption and implementation of environmental management systems and practices require financial resources (Aragón-Correa et al., 2008). Small businesses may not have the financial capacity to support these projects. Therefore, the adoption of environmental practices, especially those which go beyond the requirements set by law and may not necessarily form part of the company's main activities such as manufacturing and sales, is seen as an unnecessary burden (Masurel , 2007; Mir and Feitelson, 2007).

Even if these small companies are willing to adopt or develop more programs or activities related to environmental management for sustainability, they are still faced with the difficulty of obtaining access to funding. This becomes a major obstacle for the company to demonstrate its ES (Perrini et al., 2007).

In a study of 1,071 Danish SMEs in 2005, Pedersen (2009) noted that companies' financial resources are a determining factor of its degree of involvement in corporate social responsibility business activities. Previous studies support these findings. For example, a study of 136 Canadian manufacturing SMEs highlighted the importance of resources in a company's ability to deal with environmental issues and implement an environmental management system (Roy and Therin, 2008). Another study of 22 small business exporters in four Asian countries suggests that smaller companies tend to find it more difficult to comply with and monitor the costs of the social and environmental needs of its global buyers (Luken and Stares, 2005).

However, other factors should be considered, such as the vision of the company's founder, and the ability to manage external relations, factors which have been shown to have a significant positive impact on the intensity of the sustainability orientation of financial resources (Aragón-Correa et al., 2008). Some problems associated with the implementation of environmental initiatives should also be highlighted. These include lack of experience in environmental management, lack technical knowledge, time, as well as lack of information and training in environmental issues (Borga et al., 2009; Court, 1996; Brio and Junquera, 2003; Holland and Gibbon, 1997).

Morrow and Rondinelli (2002) found that regulatory compliance and legal security are the main reasons energy and gas companies adopt environmental practices. Other researchers have also found that government regulations are the main external factors leading to the adoption of environmental practices (Ruddell and Stevens, 1998; Clark, 1999; Chang and Wong, 2006). In this line of work, Costantinia and Mazzanti (2012) 
showed that both public policies and private innovation patterns trigger higher efficiency in the production process through complementary mechanisms, thus changing the perception of environmental protection actions as a production cost into a net benefit.

However other factors have also been identified in the adoption of environmental practices, such as customer influence (Pouliot, 1996; Ruddell and Stevens, 1998; Clark, 1999; Gavronski et al., 2008), the desire to attract new customers or enter new markets (Chan and Hawkins, 2010), the influence of suppliers (Ruddell and Stevens, 1998; Clark, 1999), the need to keep up with competitors (Ilomaki and Melanen, 2001) and social pressures in countries where the company exercises its activity (Pouliot, 1996; Stenzel, 2000; Sharma and Henriques, 2005; Chan and Wong, 2006).

However, in the case of small and medium enterprises, its local character seems to be the greatest factor, since the main stakeholders are the key factor for the adoption of environmental practices. Among the main stakeholders are: customers, local government, local society, employees and suppliers as well as competitors, insurers, banks and other businesses in the area in this order of priority (Gombault and Versteege, 1999; Hillary, 2004; Fernández-Viné et al., 2010).

This divergence of views on the role of resources in the ability of small businesses to find, develop and nurture their environmental policies is evidence of the need for more research on this subject.

Managers of small businesses may show little concern for the use of environmental tools and lack knowledge on environmental management and certification systems. A company's concern for quality management is a key to developing environmental management systems since a direct relationship has been found between them. In fact, Oxborrow and Brindley (2013) argue that: "several green initiatives like green purchasing, waste minimization, total quality management, customer-focused approach and continuous improvements are influencing most companies to go green".

To achieve a significant improvement in this area, a company must obtain adequate knowledge, develop a greater concern for environmental issues and be willing to allocate the necessary funds to develop and implement environmental programs. However, it is not easy to understand, interpret and apply the standards of environmental management systems (Biondi et al, 2000), as it requires a certain level of technical knowledge and skill. According to the results of a study by Roxas and Coetzer (2012) of 166 small businesses in the Philippines, ES is a construct comprised of three dimensions: knowledge of environmental issues, sustainable practices and a commitment towards environmental sustainability. 
The cognitive, regulatory and normative elements of the institutional environment are strongly linked to positive managerial attitudes toward environmental sustainability, which in turn, positively influences the firm's overall ES.

Another aspect that should be highlighted is the perception of small business owners that the environmental impact on their results and business strategy is low. This can be partly explained by their low awareness and understanding of environmental impacts and the risks associated with business (Young, 2010; Borga et al, 2009). They lack an understanding of these problems as well as the potential benefits of environmental improvements (Revell and Rutherfoord, 2003). Many of them think that their business performance has a negligible impact on the environment (Merritt, 1998). Furthermore, Anglada (2000) found that some owners believe that it is the government's responsibility to resolve environmental problems.

This low awareness and negative attitude towards the environment have discouraged many small businesses from implementing an environmental management system or other sustainable business practices with the environment (Revell et al., 2009).

\subsection{Environmental cooperation and small business}

Despite the aforementioned drawbacks, SMEs can benefit from addressing sustainability issues, for example, through cost savings (eg., greater energy efficiency) or by creating a competitive advantage (eg., successful new products). These issues, which may at first seem to be a complex task for some SMEs, can be resolved by collaborating with agents outside the boundaries of their organization.

Chan (2011) suggested that managers of small and medium enterprises should consider working with companies facing similar problems. Forming a local group with a common goal can help in the exchange of information on environmental management. For example, Ammenberg et al. (1999) presented a model for implementing an environmental management system in a strategic SME network. Their findings revealed positive responses from customers and cost savings from networking. Emphasizes network governance-through center coordinators and steering committees.

Collaboration with external organizations can take place in different ways, such as networking, cooperation and partnerships (Biondi et al, 2002; Bos-Brouwers, 2009; Clarke and Roome, 1999; de Bruijn and Hofman, 2000; Hartman et al., 2002; Lepoutre and Heene, 2006; Murillo and Lozano, 2009; Torri, 2010).

The main characteristics that define cooperation are streamlining business lines of small businesses and creating strategic alliances. According to Solé Parellada and Bramanti (2001), this provides access to new markets and technologies at a faster rate and with 
less capital compared to internationalization, research and development activities carried out exclusively by the company.

Furthermore, collaboration between companies without patrimonial links is a free way to work without commitments, as the collaboration can end at any time without the need to cancel contractual agreements. It also allows them to maintain their individuality while forming part of a group of companies of a certain size: concentration without centralization (Cabaleiro Casal, 2001). Therefore, this could be a potential option for SMEs wishing to participate in eco-innovation processes. Cooperation allows companies to collaborate not only with other private companies in the sector, but also with other intermediaries.

Intermediaries are third party organizations that help SMEs to achieve their desired objectives (Perset, 2010). They can provide external drive, motivation and advice to start or continue with, for example, environmental protection (Gombault and Versteege, 1999).

The literature recognizes different types of intermediaries: governments and local authorities, NGOs, academia, consultants, etc. (Afsarmanesh and Camarinha-Matos, 2009; the Bri'o and Junquera, 2003; Howells, 2006; Massa and Testa, 2008; Zeng et al., 2010). These can be classified into three distinct groups: public, nonprofit, and private intermediaries (Kolk et al, 2008). Public intermediaries are governments, scientific partners and universities (financed by public funds) as well as other publicly funded bodies (Hansen and Klewitz, 2012). NGOs belong to the nonprofit group, while consultants and industry associations fall into the private group. To explore the potential role of these intermediaries in innovation, we briefly describe the different levels of intermediation identified by Howells (2006):

- The forecast, diagnostic processing and scanning of information: At this level of SMEs intermediation, intermediaries are able to obtain a more comprehensive view of environmental problems, which implies sustainability, access to external experts and benefits from the exchange of resources (see also De Bruijn and Hofman, 2000; Bruijn and Tukker, Hartman et al.; 2002, 1999, 2002; Roome, 2001).

- Knowledge processing, collecting, and synthesis: At this level intermediaries help combine knowledge from two or more parties. This knowledge can come from different internal sources or two different organizations.

Therefore, collaboration between SMEs and their intermediaries can lead to an improvement in their innovation capacity, and more specifically, to constructing their absorptive capacity for eco-innovation. Studies like that of De Marchi (2011) show that environmental innovative firms in Lithuania cooperate with external partners on innovation to a higher extent than other innovative firms in Lithuania. 
First of all, the intermediary can help to recognize and understand new external knowledge through knowledge processing, collection and synthesis; and can help in the areas of accreditation and standards. Secondly, the assimilation of external knowledge to the firm context can be facilitated at intermediation levels of assessment and evaluation, regulation and arbitration, testing, validating and training.

Finally, the process of the creation of new knowledge can be facilitated at the marketing and intellectual property level. Therefore, by collaborating with intermediaries, SMEs are able to locate, acquire and use external knowledge for eco-innovation, and obtain access to direct assistance, thereby complementing their limited resources (eg., time, financial, human).

Cooperation can certainly play a dynamic role in ensuring the success of SMEs (Enderle, 2004; Aragon-Correa et al., 2008; Benito Hernández and Esteban Sánchez, 2012). In this sense, Halila (2007) suggests that networks can offer SMEs a forum for discussing new ideas, help them overcome isolation, and provide them with the necessary social and intellectual support for implementing new strategies or activities. So, networks can provide SMEs with important expertise or resources, which enable them to take risks or implement practices they otherwise might not have considered. Hillary (2004) also cited the absence of a business network as a barrier to the successful implementation of ISO 14001. The literature states how networks should be a key element in the development of sustainability strategies for SMEs. One of the consistent conclusions found in SMEs and sustainability literature is that participation in a network of firms involved in sustainability can provide firms with the resources and expertise they need to overcome their lack of knowledge (Stubblefield Loucks, et al., 2010).

According to Brouthers et al. (2014), the resource dependency theory proposes that cooperating with others through strategic alliances ${ }^{4}$, is one way to obtain these resources (Hillman, Withers, \& Collins, 2009). Furthermore, alliances can lead to better international performance, because alliances act as a source of new knowledge and resources that SMEs can use in order to develop their international organizational capabilities, which will help them overcome the disadvantages of smallness and foreignness in a specific country (Lu and Beamish, 2001; Cegarra-Navarro, 2005).

In conclusion, collaborative relationships can provide SMEs with the opportunity to overcome some of the barriers to implementing environmental initiatives (Brouthers, et al., 2014) associated with their size, and/or other characteristics (del Brio and Junquera, 2003) and limited absorptive capacity (Lepoutre and Heene, 2006).

\footnotetext{
${ }^{4}$ Strategic alliances are agreements between two or more companies to share knowledge and resources (Lu \& Beamish; 2001).
} 


\subsection{Theoretical model}

The various factors that influence the environmental responsibility actions of a small business are summarized in the following table:

Two theoretical schools of thought can be found in the literature review. Some authors think that resources are the main variable to consider when performing ER actions, especially in the context of small businesses (see Table 2). The lack of recurrent funding and the general lack of resources according to the cited studies mark the actions of SMEs in terms of environmental responsibility.

However, as seen in Table 2, other authors feel that other variables are equally important in the field of small business. These variables include the experience and training of entrepreneurs in environmental management issues, the perception of the business performance of ER actions, flexible organization, communication, quick decision-making, innovation policy and cooperation with third parties without linking equity.

(Table 2)

In line with recent studies, this work aims to provide more information on the relationship between cooperative business relations and the actions that small business carry out to care for the environment. Thus, we propose the following model (Figure 1).

(Figure 1)

\section{Hypotheses}

All hypotheses are tested for a sample of 930 small Spanish manufacturing firms. The literature developed in this study concludes that a good relationship with the community and other external stakeholders be an advantage for small businesses. Among the many advantages of cooperating with third parties are: cost savings, access to markets, information gathering, training and experience, and help to develop new ideas and innovative ways of implementing these ideas in the company and in the market.

Thus, according to the literature review of this study, these collaborations allow SMEs to improve their energy efficiency through cost savings, develop eco-innovations more easily, obtain access to care, training and information on the implementation of environmental management systems, compensating for their lack of experience and knowledge in this field, and solve other problems they may have in common with other members of the network in the environmental field. As collaboration is expected to favor actions on environmental responsibility, we propose the following hypothesis: 
$H_{1}$ : There is a positive relationship between environmental protection actions and business cooperation strategies in small businesses.

Moreover, the continuous improvement of these partnerships is also expected to encourage such actions. Cooperative relationships are based on the trust of its members, and therefore, there should be a continuous flow of communication and information enabling the network or cooperative structure to update and improve, modifying the needs of small businesses (Fink and Kessler, 2010). In this sense and to complete the $H_{1}, H_{2}$ arises as follows:

$\mathrm{H}_{2}$ : There is a positive relationship between environmental protection actions and the continuous improvement in third party relations in small businesses.

\section{Data Analysis and Methodology}

\subsection{Sample and data collection}

This study gathered data from the Survey on Business Strategies (ESEE, Encuesta sobre Estrategias Empresariales), which first began in 1990 thanks to an agreement between the Ministry of Science and Technology (at the time, the Ministry of Industry and Energy) and the SEPI Foundation (previously the Fundación Empresa Pública), responsible for its design and control through the Program for Economic Research. The ESEE is a statistical survey that collects data from an annual business survey sent to a panel of Spanish manufacturing companies. It collects data on various aspects related to companies' strategic behavior and decision-making as well as information on their results and account balances. The sample is representative of the Spanish manufacturing sector. Although the ESEE contains data since 1990, this paper concentrates on the years 2009-2010. One of the common characteristics of the data set is that the firms that participate in the questionnaire are selected according to a selective sampling method. The sample is comprised of firms that have between 10 and 200 employees. Table 3 shows the technical data of the study.

(Table 3)

\subsection{Variables and measures}

\subsubsection{Dependent variables}

This paper attempts to explain the social responsibility actions in the environmental dimension in the case of small businesses. In this sense, the dependent variable has been 
defined by the resources devoted to environmental protection by small businesses. This paper follows the line of research marked by other authors such as Esteban-Sánchez and Benito -Hernández (2013); Williamson et al. (2006) and Marín and Rubio Bañón Rives (2008).

\subsubsection{Independent variables}

The aim of this work is to study the influence of business cooperation on environmental responsibility actions in small businesses. To do this, we have defined two independent variables. The first is the existence of cooperative business relationships and the second is a variable that aims to complete the first and is defined as the continuous improvement of these cooperative relationships. Other studies have used these variables and their measurement to account for other parameters such as innovation, labor productivity, etc. (Esteban-Sánchez and Benito-Hernández, 2013; Platero-Jaime et al., 2014). Furthermore, De Marchi (2011) attempted to explain ecological innovation through cooperative relationships using the existence of these relationships with suppliers, customers, universities, etc. as an independent variable.

Due to the lack of separate data, in this paper data were grouped into a single variable to explain whether there are such relationships on a general basis. Since the objective of this work is to study the relationship between the existence of cooperative business relationships and environmental protection activities, it was not considered necessary to explain the different agents in the cooperative relationships.

\subsubsection{Control variables}

Schreck (2011) notes that there is no universal business model to address the different social responsibility policies. In linear regression analyses, there can be other moderators or control variables modelled in terms of interaction (Jaccard and Turrisi, 2003) such as company size, degree of internationalization or company age, among others (Schreck, 2011). This study considers the following control variables: geographical space, size, innovation and quality control. Only four variables were considered to mitigate the risk that the resulting sample sizes would be too small, and thus prevent miscalculation of regression coefficients.

With regard to the control variable which refers to geographic concentration, small businesses tend to concentrate in a small geographic area to take advantage of cross sector relationships or the proximity of a very specialized labour market and share out sources of information more efficiently. Benefits are gained from a) the flow of information among the different companies that make up a sector; b) cross sector relationships between suppliers and manufacturers of finished goods; and c) proximity to a highly specialized labour market (Maté Sanchez-Val et al., 2009). The more local 
or regional geographical area where small and micro companies frequently operate, as opposed to large companies, strengthens the effects on social responsibility performance (Esteban-Sánchez and Benito-Hernández, 2013). Their commitment to the local community is therefore greater than larger companies, and their concern for the surrounding environment becomes greater as the company becomes more local.

As a company's size determines its environmental initiatives (Elsayed, 2006), size usually represents the nature and amount of resources available to the company (Bonaccorsi, 1992; Penrose and Pitelis, 2009; lepoutre and Heene, 2006). Previous studies have found a positive relationship between company size and its environmental strategies (Martin-Tapia et al, 2010; Perrini et al., 2007).

In this sense, the resource constraints of small businesses, such as lack of time, personnel, knowledge and financial capital (Azzone and Noci, 1998; Bos-Brouwers, 2009; the Bri'o and Junquera, 2003; Spence, 1999) may lead the company to make fewer investments and therefore implement fewer eco-innovations (Noci and Verganti, 1999). Considering the limitations inherent to small businesses, their investment policy (reactive or proactive) will have a positive relationship with the number of ecoinnovations (Noci and Verganti, 1999), which will contribute to greater or lower environmental activity.

Finally, in accordance with authors like Oxborrow and Brindley (2013), we included the variable quality management, since a positive relationship is assumed between employers' concern for quality management and environmental management through standardizing procedures that respect environmental protection and the implementation of environmental management systems.

Table 4 describes the variables included in the model.

(Table 4)

\subsection{Analysis methodology}

The presented model analyzes the effects of cooperative relationships on the actions of environmental responsibility in small businesses. The model was tested for a sample of 930 small businesses with fewer than 50 employees.

Statistical regression estimation based on the binary logistic model was employed to evaluate the existence of a relationship between cooperative relations and environmental protection in small businesses. This kind of statistical analysis was applied because when the dependent variable is dichotomous, the literature agrees that the estimation of a model through an OLS regression analysis could produce bias, even 
heteroscedasticity. Thus, the use of a symmetric distribution (standard o logistic) and a maximum-likelihood estimator, as in a binary logistic model, is necessary.

Other related works have also used binary logistic models. For example, Dickson and Weaver (2011) studied the creation of small business alliances to obtain resources. Agarwal (2001) also used a binary model, in this case a probit model, to study the effects of gender inequality on prospects of cooperation and environmental sustainability. De Marchi (2011) also used a binary logistic model to study the relationship between eco-innovation and cooperative business relations.

\subsection{Results and Discussion}

The results of the descriptive statistics and correlation matrices are shown in Tables 5-7.

Tables 6.1, 6.2 and 6.3 show the frequencies of the dummy variables.

(Tables 6.1, 6.2, 6.3, and 7)

With regard to the study of descriptive statistics (Tables 4-6), 30.6\% of the firms in the sample made expenditures on environmental protection (EP), while $69.4 \%$ did not. Regarding the independent variables, only $13.2 \%$ of the firms in the sample have implemented cooperation strategies (COOP) and of these only 6.5 percent are concerned about improving and developing innovations in their cooperative relations (EXT).

With regard to the control variables, $26.3 \%$ carried out control and monitoring quality in the company and $14 \%$ invested in R \& D. Finally, it is noteworthy that approximately $85 \%$ of the sampled companies are national companies that have no international activity.

Table 8 shows the results obtained from the regression model.

(Table 8)

Regarding the control variables of the model, the concentration index of business activity does not significantly influence environmental protection activities. This may be because only $9.1 \%$ of the companies surveyed have a local character. So even though previous studies have found a positive relationship between local nature and environmental protection (Gombault and Versteege, 1999; Hillary, 2004; FernándezViné et al., 2010 among others), we have been unable to corroborate this relationship in this work.

The second control variable, size, had a significant effect on expenditure on environmental protection, with expenditure increasing with the size of the company. 
Other previously-mentioned works share this interpretation (Noci and Verganti, 1999; Rennings, 2000; Perrini et al., 2007; Bos-Brouwers, 2010; Martin-Tapia et al., 2010).

On the other hand, results show that the implementation of quality policies in a company had a significant positive effect on increased expenditure on environmental protection, as expected. Both process improvement and product enhancement significantly promote environmental protection (Van Hemel and Cramer, 2002; Rennings et al., 2006; Beise-Zee and Rennings, 2005; Oxborrow and Brindley, 2013).

Process and product innovation did not have a significant effect on increased spending on environmental protection in the case of small businesses in the industrial sector. Although other works cited in the literature explain the relationship between these two variables (Noci and Verganti, 1999; Rennings, 2000; Del Bri'o and Junquera, 2003; Luetkenhorst, 2004; Jenkins, 2006; Sweeney, 2007; Roxas, 2009; Russo and Tencati 2009), this study has not been able to verify the existence of a relationship between them.

With regard to the independent variables, the results obtained in the binary logistic regression show that the COOP variable was significant, and therefore, hypothesis $H_{1}$ can be accepted. This indicates the existence of a positive relationship between environmental protection activities and cooperative relationships with interest groups outside the company.

The obtained results show that hypothesis $H_{2}$ should also be accepted. The EXT variable was also significant, indicating a positive relationship between environmental protection activities and improvement and innovation in cooperative relationships with interest groups outside the company.

On accepting these two hypotheses, this study joins previously published works like those by Ammenberg et al., 1999; Gombault and Versteege, 1999; Hartman et al., 1999; Bruijn and Hofman, 2000; Agarwal, 2001; Roome, 2001; Bruijn and Tukker, 2002; Hillary, 2004; Hartman et al., 1999; Halila, 2007; Aragón-Correa et al., 2008; Hillman et al., 2009; Stubblefield Loucks, et al., 2010; Chan, 2011; De Marchi, 2011; and Brouthers et al., 2014, in which positive relationships were found between business cooperation and increasing environmental responsibility in the company. This study includes the EXT variable as a complementary variable to the traditionally used variable existence of business cooperation (COOP) in order to complete the above-mentioned works by including the premise in $H_{2}$. 


\section{Conclusions}

\subsection{Theoretical contributions and managerial implications}

While many large multinational companies have implemented various forms of sustainability measures given their abundant resources, little is known about the nature and extent of environmental sustainability (ES) among small businesses. Such companies are usually associated with scarce resources, a small scale of operations, and low visibility compared to large companies (Udayasankar, 2007), making it difficult for them to adopt environmental protection measures.

This study proposes how small businesses can overcome these obstacles: cooperation between companies and the establishment of strategic alliances with third parties. The results indicate that small businesses that maintain and improve their cooperative relationships through the use of networking with universities, competitors, suppliers and customers spend more on environmental protection than those which do not.

Formal partnerships allow small companies to share resources and knowledge and thereby to overcome the obstacles of lack of time, personnel, knowledge and financial capital. They also allow small companies to make better use of their advantages in terms of flexibility and adaptability to adopt their strategic environmental sustainability policies.

Cooperation can certainly play a dynamic role in ensuring the success of SMEs. Cooperation not only allows SMEs to collaborate with other private companies of the sector, but it also allows them to cooperate in innovation with public, nonprofit, and / or private external partners.

This study sheds light on how small businesses can overcome their obstacles to institutionalize and develop environmental responsibility policies. Furthermore, it provides relevant managerial implications for the managers of small businesses who want to benefit from the positive impacts related to environmental sustainability in terms of cost savings, for example through increased energy efficiency, or by promoting eco-innovation and the development of eco-friendly products.

Networking and strategic alliances with third parties should be strategically managed by the owners and managers of small businesses. Networks can provide SMEs with important expertise or resources, which enable them to take risks or implement practices they might otherwise not have considered and to overcome the obstacles created by a lack of knowledge. 


\subsection{Limitations and recommendations for future research}

The two main limitations of this paper are the national character of the sample and the temporary horizon which was limited to one year of study (a cross sectional study). However, the relationship between cooperative relationships and environmental responsibility actions is not expected to change substantially over time (Aguarwal, 2002). Finally, another notable limitation is the economic crisis that occurred in Spain during the year of study. This could have influenced business decisions regarding investments in environmental protection.

With regard to future research, it would be interesting to carry out this study with a sample of medium-sized companies (50 to 250 employees). An extension of this paper is also intended using panel data and a more in-depth analysis. It would also be interesting to break down the cooperation variable into the different agents which regularly cooperate with companies, such as universities, clients, suppliers, competitors, etc. and to repeat the study in boom years to see how it influences results, since availability and access to financial resources is key to encouraging environmental protection policies. Finally, it would be interesting to repeat this analysis with data from other countries with larger business enterprise frameworks. 


\section{Illustrations:}

Table 1. CSR: Microenterprises compared to large businesses

\begin{tabular}{|c|c|}
\hline \multicolumn{2}{|c|}{ Characteristics } \\
\hline Microenterprise & Large business \\
\hline Management $=$ property & Management $\neq$ property \\
\hline Concentrated ownership & Dispersed ownership \\
\hline Deficient control mechanisms & Subject to market control \\
\hline Informal control mechanisms & Formal control mechanisms \\
\hline Close contact with partners & Subject to strong pressure from agents \\
\hline Key presence in the local community & Rigidity, slowness of response \\
\hline Quick response & Complex business culture \\
\hline $\begin{array}{l}\text { Corporate culture dominated by the values of the } \\
\text { entrepreneur }\end{array}$ & $\begin{array}{l}\text { Diversity of relationships with agents, impersonal } \\
\text { contact }\end{array}$ \\
\hline \multicolumn{2}{|c|}{ Microenterprise } \\
\hline Advantage & Disadvantages \\
\hline Greater flexibility of response & Reduced availability of financial resources, \\
\hline Better knowledge of agents' needs & personnel ... \\
\hline More personal contact & Focus on short-term activities and tasks. No time \\
\hline Greater credibility & available for long-term objectives \\
\hline Less formal control agents & Low bargaining power with partners \\
\hline Direct influence of the values of the entrepreneur & (Administration...) \\
\hline on CSR & Lower impact and visibility than large firms \\
\hline
\end{tabular}

Table 2: Summary of the factors which influence ER performance in SMEs

\begin{tabular}{|l|l|}
\hline \multicolumn{1}{|c|}{ Factor } & \multicolumn{1}{|c|}{ Reference } \\
\hline Cultural & $\begin{array}{l}\text { Anglada, 2000 } \\
\text { Revell et al., 2009 } \\
\text { Boss-Brouwers, 2010 }\end{array}$ \\
\hline Resources & Bonaccorsi, 1992 \\
& $\begin{array}{l}\text { Holland and Gibbon, } 1997 \\
\text { Azzone and Noci, 1998 } \\
\text { Spence, 1999 } \\
\text { Del Bri'o and Junquera, 2003 } \\
\text { Galbreath, 2005 } \\
\text { Lepoutre and Heene, 2006 } \\
\text { Williamson et al., 2006 }\end{array}$ \\
\hline
\end{tabular}




\begin{tabular}{|c|c|}
\hline & $\begin{array}{l}\text { Perrini et al., } 2007 \\
\text { Fierro et al., } 2008 \\
\text { Roy and Theri, } 2008 \\
\text { Bos-Brouwers, } 2009 \\
\text { Jamali et al., } 2009 \\
\text { Pedersen, } 2009 \\
\text { Penrose and Pitelis, } 2009 \\
\text { Boss-Brouwers, } 2010 \\
\text { Sinha and Akoorie, } 2010\end{array}$ \\
\hline Communication and decision-making & $\begin{array}{l}\text { Williamson et al., } 2006 \\
\text { Fierro et al., } 2008 \\
\text { Bos-Brouwers, } 2009\end{array}$ \\
\hline Image, brand, attracting customers & $\begin{array}{l}\text { Pouliot, } 1996 \\
\text { Ruddell and Stevens, } 1998 \\
\text { Clark, } 1999 \\
\text { Williamson et al., } 2006 \\
\text { Fierro et al., } 2008 \\
\text { Gavronski et al., } 2008 \\
\text { Chan and Hawkins, } 2010\end{array}$ \\
\hline Innovation & $\begin{array}{l}\text { Noci and Verganti, } 1999 \\
\text { Rennings } 2000 \\
\text { Del Bri'o and Junquera, } 2003 \\
\text { Luetkenhorst, } 2004 \\
\text { Jenkins, } 2006 \\
\text { Sweeney, } 2007 \\
\text { Roxas, } 2009 \\
\text { Russo and Tencati, 2009; }\end{array}$ \\
\hline $\begin{array}{l}\text { Perception of environmental management } \\
\text { on results }\end{array}$ & $\begin{array}{l}\text { Merrit, } 1998 \\
\text { Revell and Tutherfoord, } 2003 \\
\text { Borga et al., } 2009 \\
\text { Young, } 2010\end{array}$ \\
\hline Experience in environmental management & $\begin{array}{l}\text { Court, } 1996 \\
\text { Holanda and Gibbon, } 1997\end{array}$ \\
\hline
\end{tabular}




\begin{tabular}{|c|c|}
\hline & $\begin{array}{l}\text { Del Brio and Junquera, } 2003 \\
\text { Borga et al., } 2009 \\
\text { Sinha and Akoorie, } 2010\end{array}$ \\
\hline Experience in quality management & $\begin{array}{l}\text { Hobson and Essex, } 2001 \\
\text { Roxas and Chadee, } 2012 \\
\text { Oxborrow and Brindley, } 2013\end{array}$ \\
\hline Knowledge and training & $\begin{array}{l}\text { Court, } 1996 \\
\text { Holanda and Gibbon, } 1997 \\
\text { Azzone and Noci, } 1998 \\
\text { Spence, } 1999 \\
\text { del Bri'o and Junquera, } 2003 \\
\text { Borga et al., } 2009 \\
\text { Bos-Brouwers, } 2009\end{array}$ \\
\hline Cooperation & $\begin{array}{l}\text { Ammenberg et al., } 1999 \\
\text { Gombault and Versteege, } 1999 \\
\text { Hartman et al., } 1999 \\
\text { Bruijn and Hofman, } 2000 \\
\text { Agarwal, } 2001 \\
\text { Roome, } 2001 \\
\text { Bruijn and Tukker, } 2002 \\
\text { Hillary, } 2004 \\
\text { Hartman et al., } 1999 \\
\text { Halila, } 2007 \\
\text { Aragon-Correa et al., } 2008 \\
\text { Hillman et al., } 2009 \\
\text { Stubblefield Loucks, et al., } 2010 \\
\text { Chan, 2011 } \\
\text { De Marchi, } 2011 \\
\text { Brouthers et al., } 2014\end{array}$ \\
\hline $\begin{array}{l}\text { Government regulations and social } \\
\text { pressures }\end{array}$ & $\begin{array}{l}\text { Pouliot, } 1996 \\
\text { Ruddell and Stevens, } 1998 \\
\text { Clark, } 1999\end{array}$ \\
\hline
\end{tabular}




\begin{tabular}{|l|l|}
\hline & Stenzel, 2000 \\
& Morrow and Rondinelli, 2002 \\
& Sharma and Henriques, 2005 \\
Chang and Wong, 2006 \\
Chan and Wong, 2006 \\
Costantinia and Mazzanti, 2012 \\
\hline Local character & $\begin{array}{l}\text { Gombault and Versteege, 1999 } \\
\text { Hillary, 2004 } \\
\text { Fernández-Viné et al., 2010 }\end{array}$ \\
\hline Suppliers and competitors & $\begin{array}{l}\text { Ruddell and Stevens, 1998 } \\
\text { Clark, 1999 } \\
\text { Ilomaki and Melanen, 2001 }\end{array}$ \\
\hline Source: author-compiled data. & \\
\hline
\end{tabular}

Source: author-compiled data.

Table 3. Technical data of the study

\begin{tabular}{|c|c|}
\hline \multicolumn{2}{|l|}{ Population } \\
\hline Unit & Spanish manufacturing sector \\
\hline Questionnaire design & SEPI Foundation \\
\hline Population types & More than 100,000 elements. \\
\hline Time period & Data from 2009 \\
\hline \multicolumn{2}{|l|}{ Sampling } \\
\hline Type of sampling & $\begin{array}{l}\text { Random stratified census according to activity sector } \\
\text { and firm size. }\end{array}$ \\
\hline Sample size & 930 Small Spanish manufacturing firms \\
\hline Sampling error (aprox) & $0.028(\mathrm{p}=\mathrm{q}=0.50)$ \\
\hline Level of confidence & $95 \%(\mathrm{~K}=2$ sigma $)$ \\
\hline Data treatment & $\begin{array}{l}\text { Statistical Solutions for Products and Services } \\
\text { (SPSS). }\end{array}$ \\
\hline
\end{tabular}

Source: author-compiled data.

Table 4. Variables of the proposed models.

\begin{tabular}{|l|l|l|l|l|l|l|}
\hline $\begin{array}{l}\text { Variable } \\
\text { Type }\end{array}$ & $\begin{array}{l}\text { Study } \\
\text { variables }\end{array}$ & $\begin{array}{l}\text { Variable to } \\
\text { analyze }\end{array}$ & Definition & Name & Source & $\begin{array}{l}\text { Values and data } \\
\text { year }\end{array}$ \\
\hline \multirow{2}{*}{ Dependent } & $\begin{array}{l}\text { Environmental } \\
\text { protection }\end{array}$ & $\begin{array}{l}\text { Expenditures } \\
\text { on }\end{array}$ & $\begin{array}{l}\text { Value of } \\
\text { environmental } \\
\text { production of } \\
\text { goods and }\end{array}$ & $\begin{array}{l}\text { gorion } \\
\text { services and }\end{array}$ & $\begin{array}{l}\text { Data } \\
\text { from the } \\
\text { Survey } \\
\text { on }\end{array}$ & $\begin{array}{l}\text { 1=Expenditures } \\
\text { on environmental } \\
\text { protection. } \\
2=\end{array}$ \\
\hline
\end{tabular}




\begin{tabular}{|c|c|c|c|c|c|c|}
\hline & & & $\begin{array}{l}\text { other current } \\
\text { income, in } \\
\text { thousands of } \\
\text { Euros, divided } \\
\text { by the Average } \\
\text { Total Staff }\end{array}$ & & \multirow[t]{3}{*}{$\begin{array}{l}\text { Business } \\
\text { Strategies }\end{array}$} & $\begin{array}{ll}\text { expenditures on } \\
\text { environmental } \\
\text { protection. }\end{array}$ \\
\hline & \multirow[b]{2}{*}{ Cooperation } & $\begin{array}{l}\text { Business } \\
\text { Cooperation } \\
\text { Networks }\end{array}$ & $\begin{array}{l}\text { Indicates } \\
\text { whether the } \\
\text { firm uses } \\
\text { networks of } \\
\text { cooperation } \\
\text { with } \\
\text { universities, } \\
\text { competitors, } \\
\text { suppliers and } \\
\text { customers to } \\
\text { work. }\end{array}$ & $\mathrm{COOP}$ & & $\begin{array}{l}0=\text { No cooperative } \\
\text { relationships. } \\
1=\text { Cooperative } \\
\text { relationships. }\end{array}$ \\
\hline Independent & & $\begin{array}{l}\text { Continuous } \\
\text { improvement } \\
\text { of external } \\
\text { relations }\end{array}$ & $\begin{array}{l}\text { Indicates } \\
\text { whether the } \\
\text { firm introduced } \\
\text { new } \\
\text { organizational } \\
\text { methods, } \\
\text { related to new } \\
\text { methods of } \\
\text { management of } \\
\text { external } \\
\text { relationships } \\
\text { with other } \\
\text { companies or } \\
\text { public } \\
\text { institutions. }\end{array}$ & EXT & & $\begin{array}{l}0=\text { No attempts to } \\
\text { improve } \\
\text { cooperative } \\
\text { relations. } \\
1=\text { Improved } \\
\text { cooperative } \\
\text { relations. }\end{array}$ \\
\hline Control & Innovation & $\begin{array}{l}\text { Innovation } \\
\text { and } \\
\text { improvement } \\
\text { of processes } \\
\text { and products }\end{array}$ & $\begin{array}{l}\text { Percentage of } \\
\text { total } \\
\text { expenditure on } \\
\text { R\&D on sales } \\
\text { volume }\end{array}$ & INN & & $\begin{array}{l}0=0 \% \\
1=\text { de } 0 \text { a } 1 \% \\
2=\text { de } 1 \text { a } 2.5 \% \\
3=\text { de } 2.5 \text { a } 5 \% \\
4=\text { de } 5 \text { a } 10 \% \\
5=\text { más de } 10 \% \\
(2009)\end{array}$ \\
\hline
\end{tabular}




\begin{tabular}{|c|c|c|c|c|}
\hline $\begin{array}{l}\text { Geographical } \\
\text { coverage }\end{array}$ & $\begin{array}{l}\text { Geographical } \\
\text { coverage of } \\
\text { the activity of } \\
\text { the company }\end{array}$ & $\begin{array}{l}\text { Reflects the } \\
\text { geographic } \\
\text { scope of the } \\
\text { principal } \\
\text { market in } \\
\text { which the } \\
\text { company sells }\end{array}$ & $\mathrm{COV}$ & $\begin{array}{l}1=\text { local } \\
2=\text { provincial } \\
3=\text { regional } \\
4=\text { national } \\
5=\text { exterior } \\
6=\text { interior and } \\
\text { exterior }\end{array}$ \\
\hline Size & Firm Size & $\begin{array}{l}\text { Indicates the } \\
\text { size of the firm } \\
\text { measured by } \\
\text { the logarithm } \\
\text { of sales. }\end{array}$ & SIZ & Log of sales. \\
\hline Quality & $\begin{array}{l}\text { Improving the } \\
\text { quality of } \\
\text { processes and } \\
\text { services }\end{array}$ & $\begin{array}{l}\text { Indicates } \\
\text { whether the } \\
\text { firm has } \\
\text { conducted or } \\
\text { contracted } \\
\text { standardization } \\
\text { and quality } \\
\text { control. }\end{array}$ & QUA & $\begin{array}{ll}0=\quad \text { No } & \text { quality } \\
\text { control. } & \\
1= & \text { Quality } \\
\text { control. } & \end{array}$ \\
\hline
\end{tabular}

Source: author-compiled data.

Table 5. Descriptive statistics

\begin{tabular}{l|llll} 
Small Business (n=929) & Min. Max. Mean Standard Deviation
\end{tabular}

\begin{tabular}{c|cccc}
\hline EP & 1 & 2 & 1.74 & 0.461 \\
QUA & 1 & 2 & 1.73 & 0.441 \\
INN & 0 & 5 & 1.89 & 0.921 \\
COOP & 1 & 2 & 1.94 & 0.742 \\
EXT & 1 & 2 & 1.93 & 0.246 \\
COV & 1 & 6 & 3.682 & 0.421 \\
SIZ & 1.70 & 6.77 & 5.7099 & 0.34044
\end{tabular}

Table 6.1. Frequencies of dichotomous variables

\begin{tabular}{c|cccc} 
Values & EP (\%) & QUA $(\%)$ & COOP $(\%)$ & EXT $(\%)$ \\
\hline Yes & 30.6 & 26.3 & 13.2 & 6.5 \\
Not & 69.4 & 73.7 & 86.3 & 93.5
\end{tabular}




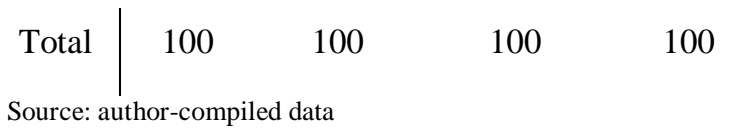

Table 6.2 Frequencies of ordinal variable "COV"

\begin{tabular}{c|c} 
Values & COV $(\%)$ \\
Local & 9.1 \\
Provincial & 13.5 \\
Regional & 15.3 \\
Interior & 43.3 \\
Exterior & 3.9 \\
Interior and exterior & 14.8 \\
Total & 100
\end{tabular}

Tabla 6.3 Frequencies of ordinal variable "INN"

\begin{tabular}{c|c} 
& INN (\%) \\
\hline 1=de 0 a $1 \%$ & 6 \\
2=de 1 a $2.5 \%$ & 1.9 \\
3=de 2.5 a 5\% & 2.3 \\
4=de 5 a $10 \%$ & \\
4=de 5 a $10 \%$ & 2.6 \\
5=más de 10\% & 8 \\
Total & 100 \\
Source: author-compiled data
\end{tabular}

Table 7. Correlation matrix

\begin{tabular}{c|ccccccc} 
& EP & QUA & INN & COOP & EXT & COV & SIZ \\
\hline EP & 1 & & & & & \\
QUA & $0.158(* *)$ & 1 & & & & \\
INN & $-0.176(* *)$ & $-0.262(* *)$ & 1 & & & \\
& & & & & & &
\end{tabular}




\begin{tabular}{|c|c|c|c|c|c|c|}
\hline COOP & $0.182(* *)$ & $0.271(* *)$ & $-0.710(* *)$ & 1 & & \\
\hline EXT & $0.091(* *)$ & 0.052 & $-0.101(* *)$ & $0.079(*)$ & 1 & \\
\hline $\mathrm{COV}$ & $0.321(* *)$ & $0.160(* *)$ & $-0.143(* *)$ & $0.127(* *)$ & 0.049 & 1 \\
\hline SIZ & $-0.191(* *)$ & $-0.136(* *)$ & $0.223(* *)$ & $-0.211(* *)$ & $-0.074\left(^{*}\right)$ & $-0.131(* *)$ \\
\hline
\end{tabular}

For each pair of continuous variables, Pearson's Correlation Coefficient is reported; in the opposite case, Spearman's $* \mathrm{p}<0.05$; ** $\mathrm{p}<0.01$.

Source: author-compiled data.

Table 8. Binary logistic regression results

\begin{tabular}{|c|c|c|c|}
\hline Model & \multicolumn{3}{|c|}{$\left(E P_{i t}\right)=\beta_{0}+\beta_{1} Q U A_{i t}+I N N_{i t} \beta_{2}+\beta_{3} N E T_{i t}+\beta_{4} E X T_{i t}+\beta_{5} C O V_{i t}+\beta_{6} S I Z_{i t}+\varepsilon_{i t}$} \\
\hline Variables & Hypotheses & Expected Directions & Values \\
\hline QUA & - & + & $\begin{array}{c}\mathbf{0 . 4 0 4} * * \\
(0.168)\end{array}$ \\
\hline INN & - & + & $\begin{array}{l}-0.029 \\
(0.098)\end{array}$ \\
\hline COOP & $\mathrm{H}_{1}$ & + & $\begin{array}{c}\mathbf{0 . 5 4 7} * * \\
(0.271)\end{array}$ \\
\hline EXT & $\mathrm{H}_{2}$ & + & $\begin{array}{l}\mathbf{0 . 5 2 0} * \\
(0.281)\end{array}$ \\
\hline $\mathrm{COV}$ & - & - & $\begin{array}{l}-0.016 \\
(0.056)\end{array}$ \\
\hline SIZ & - & + & $\begin{array}{c}\mathbf{0 . 9 0 6 * * *} \\
(0.188)\end{array}$ \\
\hline Const. & - & & $\begin{array}{c}\mathbf{3 . 8 5 0} * * * \\
(1.504)\end{array}$ \\
\hline $\mathrm{R}^{2}$ & & 0.19 & \\
\hline Chi square & & 71.98 & \\
\hline
\end{tabular}


Figure 1. Relationship between business cooperation and the ES performance of small businesses

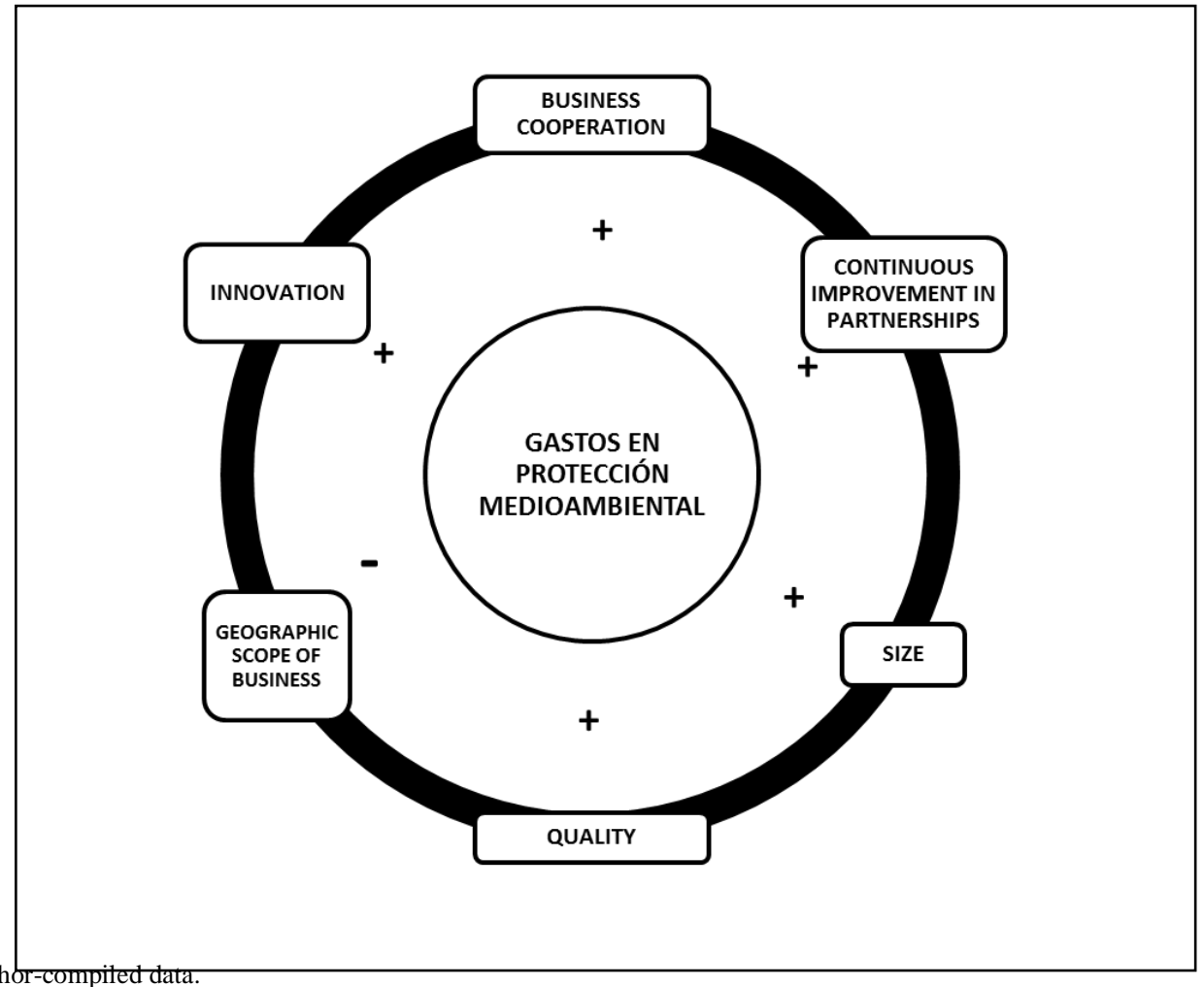




\section{References:}

Afsarmanesh H, Camarinha-Matos LM. 2009. On the classification and management of virtual organization breeding environments. International Journal of Information Technology and Management 8(3): 234-59.

Agarwal B. 2002. Gender inequality, cooperation and environmental sustainability. In a workshop on "Inequality, Collective Action and Environmental Sustainability", Working Paper October: 02-10.

Agarwala T. 1993. Corporate environmental strategy: a perspective and a theoretical framework. Social Responsibility Journal 1(3/4): 167-78.

Anglada, ML. 2000. Small and medium-sized enterprises perceptions of the environment. In R. Hillary (Ed.), Greenleaf Publishing, Small and Medium-Sized Enterprises and the Environment, Sheffield, UK.

Aragón-Correa JA, Hurtado-Torres N, Sharma S, García-Morales VJ. 2008. Environmental strategy and performance in small firms: A resource-based perspective. Journal of environmental management 86(1): 88-103.

Aragón-Correa JA, Rubio-López E. 2007. Proactive corporate environmental strategies: myths and misunderstandings. Long Range Planning 40(3): 357-381.

Azzone G, Noci G. 1998. Seeing ecology and 'green' innovations as a source of change. Journal of Organizational Change Management 11(2): 94-111.

Bagur-Femenias Ll, Llach J, Alonso-Almeida, MM. 2013. Is the adoption of environmental practices a strategical decision for small service companies? An empirical approach. Management Decision 51(1): 41-62, DOI $10.1108 / 00251741311291300$

Barney JB 1991. Firm resources and sustained competitive advantage. Journal of Management 17(1): 99-120.

Battisti M, Perry M. 2011. Walking the Talk? Environmental Responsibility from the Perspective of Small-Business Owners. Corporate Social Responsibility and Environmental Management 18: 172-185. DOI: 10.1002/csr.266

Beise M, Rennings K. 2005. Lead markets and regulation: a framework for analyzing the international diffusion of environmental innovations. Ecological Economics 52: 5-17.

Benito-Hernández S, Esteban-Sánchez P. 2008. Aplicación de los principios de responsabilidad social en las empresas de participación de menos de diez empleados. REVESCO-Revista de Estudios Cooperativos 94: 7-26.

Benito-Hernández S, Platero-Jaime M, Rodríguez-Duarte A. 2012. Factores determinantes de la innovación en las microempresas españolas: la importancia de los factores internos. Universia Business Review 33: 104-121.

Benito-Hernández S, Platero-Jaime M. 2012. Las microempresas en tiempos de crisis: análisis de la formación, la experiencia y la innovación. Revista de Estudios Cooperativos REVESCO. 108: 7-38.

Benito-Hernández, S. Esteban-Sánchez P. (2012). La influencia de las políticas de responsabilidad social y la pertenencia a redes de cooperación en el capital relacional y estructural de las microempresas. Investigaciones Europeas de Dirección y Economía de la Empresa 18:166-176.

Biondi V, Frey M, Iraldo F. 2000. EMS and SMEs - motivations, opportunities and barriers related to EMAS and ISO 14001 implementation, Greenleaf Publishing.

Bonaccorsi A. 1992. On the relationship between firm size and export intensity. Journal of International Business Studies 23(4): 605-35.

Borga F, Citterio A, Noci G, Pizzurno E. 2009. Sustainability report in small enterprises: case studies in Italian furniture companies. Business Strategy and the Environment 18(3): 162-76.

Bos-Brouwers H. 2010. Corporate sustainability and innovation in SMEs: evidence of themes and activities in practice. Business Strategy and the Environment 19(7): 417-35.

Brand MJ, Dam L. 2009. Corporate social responsibility in small firms - illusion or big business? Empirical evidence from The Netherlands. RENT 2009 conference, Budapest, Hungary.

Brouthers KD, Nakos G, Dimitratos P. 2014. SME Entrepreneurial Orientation, International Performance, and the Moderating Role of Strategic Alliances. Entrepreneurship Theory and Practice, DOI: 10.1002/bse.652 
Brundtland Commission 1987. Our Common Future, Report of the World Commission on Environment and Development, published as an Annex to General Assembly Document A/42/427, Development and International Cooperation. Environment. August 2, World Commission on Environment and Development.

Cabaleiro Casal MJ. 2001. Redes de empresas: propuesta de crecimiento externo para las sociedades cooperativas. Revista de Estudios Cooperativos REVESCO 74: 7-23.

Cambra-Fierro J, Hart S, Polo-Redondo, Y. 2008. Environmental respect: Ethics or simply business? A study in the small and medium (SME) context. Journal of Business Ethics 82(3): 645-656.

Cegarra-Navarro J. 2005. An empirical investigation of organizational learning through strategic alliances between SMEs. Journal of Strategic Marketing 13(1): 3-16.

Chan ESW, Hawkins R. 2010. Attitude towards EMSs in an international hotel: an exploratory case study. International Journal of Hospitality Management 29(4): 641-51.

Chan ESW, Wong SCK. 2006. Motivations for ISO 14001 in the hotel industry. Tourism Management 27(3): 481-92. Chin WW. 1998. Issues and opinion on structural equation.

Chan ESW. 2011. Implementing Environmental Management Systems in Small-and Medium-Sized Hotels: Obstacles. Journal of Hospitality \& Tourism Research 35(1): 3-23.

Clark D. 1999. What drives companies to seek ISO 14000 certification? Pollution Engineering International, Summer: $14-15$.

Clarke S, Roome N. 1999. Sustainable business: learning action networks as organizational assets. Business Strategy and the Environment 8(5): 296-310.

Clemens B. 2006. Economic Incentives and Small Firms: Does It Pay to Be Green? Journal of Business Research 59: 492-500.

Costantini V, Mazzanti M. 2012. On the green and innovative side of trade competitiveness? The impact of environmental policies and innovation on EU exports. Research Policy 41(1): 132-153.

Court P. 1996. Encouraging the Use of Environmental Management Systems in the Small and Medium Sized Business Sector. Green College Centre for Environmental Policy and Understanding. University of Oxford, Oxford.

Daily GC, Walker BH. 2000. Seeking the great transition. Nature 403: 243-245. d'Amboise G, Muldowney M. 1988. Management theory for small business: attempts and requirements. Academy of Management Review 13: 226-240.

Dangelico R, Pujari D. 2010. Mainstreaming green product innovation: why and how companies integrate environmental sustainability. Journal of Business Ethics 95(3): 471-86.

de Bruijn T, Hofman P. 2000. Pollution prevention in small and medium-sized enterprises: evoking structural changes through partnerships. Greener Management International 30: 71-82.

de Bruijn T, Tukker A. 2002. Building Alliances for a Sustainable Future. (Eds), Partnership and Leadership, Kluwer, Dordrecht: $21-40$.

De Marchi V. 2011. Environmental innovation and R\&D cooperation: empirical evidence from Spanish manufacturing firms. Research Policy. DOI: 10.1016/j.respol.2011.10.002

Del Brío JA, Junquera B. 2003. A review of the literature on environmental innovation management in SMEs: Implications for public policies. Technovation 23(12): 939-948.

Dickson PH, Weaver KM. 2011. Institutional Readiness and Small to Medium-Sized Enterprise Alliance Formation. Journal of Small Business Management 49(1): 126-148.

Dobers P, Wolff R. 2000. Competing with 'soft' issues: from managing the environment to sustainable business strategies. Business Strategy and the Environment 9: 143-150.

Dunphy D, Griffiths A, Benn S. 2003. Organizational Change for Corporate Sustainability. Routledge: New York.

Elkington J. 1994. Towards the sustainable corporation: win-win-win business strategies for sustainable development. California Management Review 36(2): 90-100.

Elsayed K. 2006. Reexamining the expected effect of available resources and firm size on firm environmental orientation: An empirical study of UK firms. Journal of Business Ethics 65(3): 297-308. 
Esty D, Winston A. 2009. Green to Gold, John Wiley and Sons Inc, Hoboken, NJ.

Evans N, Sawyer J. 2010. CSR and stakeholders of small business in regional South Australia. Social Responsibility Journal 6(3): 433-451.

Fernández B, Souto F. 2009. Crisis and Corporate Social Responsibility: Threat or Opportunity? International Journal of Economic Sciences and Applied Research 2(1): 36-50.

Fernández-Viñé MB, Gómez-Navarro T, Capuz-Rizo SF. 2010. Eco-efficiency in the SMEs of Venezuela. Current status and future perspectives. Journal of Cleaner Production 18(8): 736-46.

Fink M, Kessler A. 2010. La cooperación, la confianza and rendimiento - Resultados empíricos de tres países. British Journal of Management 21: 469-483.

Fuller T, Tian Y. 2006. Social and symbolic capital and responsible entrepreneurship: An empirical investigation of SME Narratives. Journal of Business Ethics 67(3): 287-304.

Gadenne DL, Kennedy J, McKeiver, C. 2009. An empirical study of environmental awareness and practices in SMEs. Journal of Business Ethics 84(1): 45-63.

Galbreath, J. 2005. Which resources matter the most to firm success? An exploratory study of resource-based theory. Technovation 25: 979-87.

Gavronski I, Ferrer G, Paiva EL. 2008. ISO 14001 certification in Brazil: motivations and benefits. Journal of Cleaner Production 16(1): 87-94.

Gombault M, Versteege S. 1999. Cleaner production in SMEs through a partnership with (local) authorities: successes from The Netherlands. Journal of Cleaner Production 7 (4): 249-61.

González-Benito J, González-Benito Ó. 2005. Environmental proactivity and business performance: an empirical analysis. Omega 33(1): 1-15.

Halila F. 2007. Networks as a means of supporting the adoption of organizational innovations in SMEs: the case of environmental management systems (EMSs) based on ISO 14001. Corporate Social Responsibility and Environmental Management 14(3): 167-81.

Hansen EG, Klewitz, J. 2012. Publicly mediated inter-organizational networks: a solution for sustainability-oriented innovation in SMEs? In Wagner, M. (Ed.), Entrepreneurship, Innovation and Sustainability, Greenleaf, Sheffield, 255-78.

Hartman C, Hofman P, Stafford E. 2002. Environmental collaboration: potential and limits. In de Bruijn T, Tukker A. (Eds), Partnership and Leadership: Building Alliances for a Sustainable Future, Kluwer, Dordrecht, 21-40.

Hawken P, Lovins A, Hunter Lovins L. 1999. Natural capitalism: Creating the next industrial revolution. Boston: Little Brown.

Herren A, Hadley J. 2010. Barriers to environmental sustainability facing small businesses in Durham, NC. Master's Thesis, Duke's Nicholas School of the Environment, Duke University, North Carolina.

Hillary R. 2004. Environmental management systems and the smaller enterprise. Journal of Cleaner Production 12(6): 561-9.

Hillman AJ, Withers MC, Collins BJ. 2009. Resource dependence theory: A review. Journal of Management 35(6): $1404-1427$.

Holland L, Gibbon J. 1997. SMEs in the metal manufacturing, construction and contracting service sectors: environmental awareness and actions. Eco-Management and Auditing 4: 7-14.

Howells J. 2006. Intermediation and the role of intermediaries in innovation. Research Policy 35(5): 715-728.

Ilomaki M, Melanen M. 2001. Waste minimisation in small and medium-sized enterprises - do environmental management systems help? Journal of Cleaner Production 9(3): 209-217.

Jaccard J, Turrisi R. 2003. Interaction effects in multiple regression (2nd ed.). Thousand Oaks: Sage.

Jamali D, Zanhour M, Keshinian T. 2009. Peculiar strengths and relational attributes of SMEs in the context of CSR. Journal of Business Ethics 87: 355-377. 
Jenkins H. 2006. Small business champions for corporate social responsibility. Journal of Business Ethics 67: 241256.

Jordan GJ, Fortin MJ. 2002. Scale and topology in the ecological economics sustainability paradigm. Ecological Economics 41: 361-366.

Keijzers G. 2005. Business, government and sustainable development. Milton Park: Routledge.

Kleine A, Hauff M. 2009. Sustainability-driven implementation of corporate social responsibility: application of the integrative sustainability triangle. Journal of Business Ethics 85(3): 517-533.

Kolk A, van Tulder R, Kostwinder E. 2008. Business and partnerships for development. European Management Journal 26(4): 262-73.

Kuckertz A, Wagne M. 2010. The influence of sustainability orientation on entrepreneurial intentions - investigating the role of business experience. Journal of Business Venturing 25: 524-539.

Lee S, Klassen R. 2008. Drivers and enablers that foster environmental management capabilities in small- and medium-sized suppliers in supply chains. Production \& Operations Management 17(6): 573-586.

Leonidou CN, Leonidou LC, Fotiadis TA, Zeriti A. 2013. Resources and Capabilities as Drivers of Hotel Environmental Marketing Strategy: Implications for Competitive Advantage and Performance. Tourism Management 35: 94-110.

Leonidou CN, Leonidou LC. 2011. Research into Environmental Marketing/ Management: A Bibliographic Analysis. European Journal of Marketing 45(1/2): 68-103.

LePoutre J, Heene A. 2006. Investigating the impact of firm size on small business social responsibility: a critical review. Journal of Business Ethics 67(3): 257-73.

Lepoutre, J. and Heene, A. (2006), "Investigating the impact of firm size on small business social responsibility: a critical review", Journal of Business Ethics, Vol. 67, pp. 257-73.

Lu J, Beamish P. 2001. The internationalization and performance of SMEs. Strategic Management Journal 22(6/7): $565-586$

Luetkenhorst W. 2004. Corporate social responsibility and the development agenda. The case for involving small and medium enterprises. Intereconomics 2: 157-66.

Luken R, Stares R. 2005. Small business responsibility in developing countries: a threat or an opportunity. Business Strategy and the Environment 14: 38-53.

Luken R, Stares R. 2005. Small business responsibility in developing countries: a threat or an opportunity. Business Strategy and the Environment 14: 38-53.

Lynch-Wood G, Williamson D, Jenkins W. 2009. The overreliance on self-regulation in CSR policy. Business Ethics: A European Review 18(1): 52-65.

Lynne G. 2008. Green to gold: business and industry moving onto the eco-path. Cornhusker Economics, University of Lincoln, Nebraska, 30 January.

Maddox J. 2000. Positioning the goalposts. Nature 403: 139.

Markley M, Davis L. 2007. Exploring competitive advantage through sustainable supply chains. International Journal of Physical Distribution and Logistics 37(9): 763-774.

Martin-Tapia I, Aragon-Correa J, Rueda-Manzanares A. 2010. Environmental strategy and exports in medium, small and micro-enterprises. Journal of World Business 45: 266-275.

Massa S, Testa S. 2008. Innovation and SMEs: misaligned perspectives and goals among entrepreneurs, academics, and policy makers. Technovation 28(7): 393-407.

Masurel E. 2007. Why SMEs invest in environmental measures: sustainability evidence from small and mediumsized printing firms. Business Strategy and the Environment 16: 190-201.

Maté Sánchez Val M, García Pérez de Lema D, López Hernández FA. 2009. Efectos espaciales en la convergencia de la productividad de las Pymes españolas. Revista Española de Financiación y Contabilidad 38(141): 13-36. 
McEwen T. 2013. An examination of the barriers that impact the implementation of environmental sustainability practices in small businesses. Journal of Business \& Entrepreneurship Fall: 117-139.

Melnyk S, Handfield R, Calatone RC. 2001. Integrating environmental concerns into the design process: the gap between theory and practice. IEEE Transactions on Engineering Management, 48(2): 189-208.

Merritt Q. 1998. EM into SME won't Go? Attitudes, awareness and practices in the London Borough of Croydon. Business Strategy and the Environment 7(2): 90-100.

Miles MP, Covin JG. 2000. Environmental Marketing: A Source of Reputational, Competitive, and Financial Advantage. Journal of Business Ethics 23: 299-311.

Mir D, Feitelson E. 2007. Factors affecting environmental behaviour in micro-enterprises: laundry and motor vehicle repair firms in Jerusalem. International Small Business Journal 25(4): 383-415.

Morrow D, Rondinelli D. 2002. Adopting corporate environmental management systems: motivations and results of ISO 14001 and EMAS certification. European Management Journal 20(2): 159-71.

Murillo D, Lozano J. 2009. Pushing forward SME CSR through a network: an account from the Catalan model. Business Ethics: A European Review 18(1): 7-20.

Noci G, Verganti R. 1999. Managing ‘green’ product innovation in small firms. R\&D Management 29(1): 3-15.

Ostrom AL, Bitner MJ, Brown SW, Burkhard KA, Goul M, Smith-Daniels V, Demirkan H,. Rabinovich E. 2010. Moving Forward and Making a Difference: Research Priorities for the Science of Service. Journal of Service Research 13(1): 4-36.

Oxborrow L, Brindley C. 2013. Adoption of "eco-advantage" by SMEs: emerging opportunities and constraints. European Journal of Innovation Management 16(3): 355-375. DOI 10.1108/EJIM-09-2011-0079

Pedersen E. 2009. The many and the few: rounding up the SMEs that manage CSR in the supply chain. Supply Chain Management: An International Journal 14(2): 109-16.

Penrose E, Pitelis C. 2009. The Theory of the Growth of the Firm, 4th ed., Oxford University Press, Oxford.

Perrini F, Russo A, Tencatai A. 2007. CSR strategies of SMEs and large firms: evidence from Italy. Journal of Business Ethics 74(3): 285-300.

Perrini F. 2006. SMEs and CSR theory: evidence and implications from an Italian perspective. Journal of Business Ethics 67(3): 305-16.

Perset K. 2010. The Economic and Social Role of Internet External Organizations, OECD, Paris, 1-49.

Platero-Jaime M. 2014. La innovación en la empresa española: ¿el tamaño importa? Revista APD: Asociación para el Progreso de la Dirección 294: 28-31

Pouliot C. 1996. ISO 14000: beyond compliance to competitiveness. Manufacturing Engineering 116(5): 51-56.

Ranganathan J, Willis A. 1999. The Global Reporting Initiative; an Emerging Tool for Corporate Accountability. World Resources Institute. http:// www.wri.org [15 April 2012].

Rao P, Singh AK, O'Castillo O, Intal PS Jr, Sajid A. 2009. A metric for corporate environmental indicators...for small and medium enterprises in the Philippines. Business Strategy and the Environment 18(1): 14-31. DOI: $10.1002 / \mathrm{bse} .555$

Rațiu P, Mortan M (2014). Dynamics of certified environmental management systems: ISO 14001 and EMAS in Romania. Annales Universitatis Apulensis Series Oeconomica 16(1): 198-211

Rennings K. 2000. Redefining innovation - eco-innovation research and the contribution from ecological Economics. Ecological Economics 32: 319-332.

Revell A, Rutherford R. 2003. UK environmental policy and the small firm: broadening the focus. Business Strategy and the Environment 12: 26-35. DOI: 10.1002/bse.347

Rives LM, Bañón AR. 2008. ¿Moda o factor competitivo? Un estudio empírico de responsabilidad social corporativa en Pyme. Información comercial española 842: 177-193. 
Roxas B, Chadee D. 2012. Environmental sustainability orientation and financial resources of small manufacturing firms in the Philippines. Social Responsibility Journal 8(2): 208-226, DOI 10.1108/17471111211234842

Roxas B, Coetzer A. 2012. Institutional environment, managerial attitudes and environmental sustainability orientation of small firms. Journal of Business Ethics 111(4): 461-476.

Roxas H, Lindsay V, Ashill N, Victorio A. 2009. Economic accountability in the context of local governance in the Philippines: a structural equation modelling approach. Asia Pacific Journal of Public Administration 31(1): 17-38.

Roy M, Therin F. 2008. Knowledge acquisition and environmental commitment in SMEs. Corporate Social Responsibility and Environmental Management 15: 249-59.

Ruddell S, Stevens JA. 1998. The adoption of ISO 9000, ISO 14001, and the demand for certified wood products in the business and institutional furniture industry. Forest Products Journal 48(3): 19-26.

Russo A, Tencati A. 2009. Formal vs. informal CSR strategies: Evidence from Italian micro, small, medium-sized, and large firms. Journal of Business Ethics 85(2): 339-353.

Russo MV, Fouts PA. 1997. A resource-based perspective on corporate environmental management and profitability. Academy of Management Journal 40(3): 534-559.

Sánchez PE, Benito-Hernández S. 2013. CSR Policies: Effects on Labour Productivity in Spanish Micro and Small Manufacturing Companies. Journal of Business Ethics December 1-20. DOI 10.1007/s10551-013-1982-x

Schmitter DN. (2012). A study of the barriers to the implementation of environmentally responsible practices in Indiana manufacturing businesses. Master's Thesis, Purdue University, West Lafayette, Indiana

Schreck P. 2011. Reviewing the business case for corporate social responsibility: New evidence and analysis. Journal of Business Ethics 103: 167-188.

Sharma A, Iyer GR, Mehrotra A, Krishnan R. 2010. Sustainability and business to business marketing: a framework and implications. Industrial Marketing Management 39(2): 330-341.

Sharma S, Henriques I. 2005. Stakeholder influences on sustainability practices in the Canadian forest products industry. Strategic Management Journal 26(2): 159-80.

Shuman JC, Seeger JA. 1986. The theory and practice of strategic management in smaller rapid growth firms. American Journal of Small Business 11(1): 7-18.

Sinha P, Akoorie M. 2010. Sustainable environmental practices in the New Zealand wind industry: an analysis of perceived institutional pressures and the role of exports. Journal of Asia-Pacific Business 11(1): 50-74.

Solé Parellada F, Bramant A. 2001. El por qué las redes de cooperación tecnológica. Quaderns de tecnología 4: 114117.

Stenzel PL. 2000. Can the ISO 14000 series environmental management standards provide a viable alternative to government regulation? American Business Law Journal 37(2): 237-99.

Stubblefield Loucks E, Martens ML, Cho CH. 2013. Engaging small- and medium sized businesses in sustainability. Sustainability Accounting, Management and Policy Journal 1(2): 178-200, DOI 10.1108/20408021011089239

Sweeney L. 2007. Corporate social responsibility in Ireland: barriers and opportunities experienced by SMEs when undertaking CSR. Corporate Governance 7(4): 516-523.

Tilley F, Fuller T. (2000). Foresighting methods and their role in researching small firms and sustainability. Futures 32: 149-61.

Tilley F. 2000. Small firm environmental ethics: How deep do they go? Business Ethics: A European Review 9(1): $31-41$.

Torri MC. 2010. Community-based enterprises: a promising basis towards an alternative Entrepreneurial model for sustainability enhancing livelihoods and promoting socioeconomic development in rural India. Journal of Small Business and Entrepreneurship 23(2): 237-48.

Udayasankar K. 2008. Corporate social responsibility and firm size. Journal of Business Ethics 83: 167-75. 
Uhlaner LM, Berent-Braun MM, Jeurissen RJM, de Wit G. 2012. Beyond Size: Predicting Engagement in Environmental Management Practices of Dutch SMEs. Journal of Business Ethics 109: 411-429, DOI $10.1007 / \mathrm{s} 10551-011-1137-\mathrm{x}$

van Hemel C, Cramer J. 2002. Barriers and stimuli for eco design in SMEs. Journal of Cleaner Production 10: 439453.

Van Marrewijk M, Werre M. 2002. Multiple levels of corporate sustainability. ECSF, http://www.ecsf.info [15 april 2008]

Wernerfelt B. 1984. A resource-based view of the firm. Strategic Management Journal 5(2): 171-180.

Williamson D, Lynch-Wood G, Ramsay J. 2006. Drivers of environmental behavior in manufacturing SMEs and the Implications for CSR. Journal of Business Ethics 67(3) 317-330.

Wilson EO. 2002. The future of life. New York, NY: Knopf.

Zeng S, Xie X, Tam C. 2010. Relationship between cooperation networks and innovation performance of SME. Technovation 30(3): 181-194.

Zwetsloot G, van Marrewijk M. 2004. From quality to sustainability. Journal of Business Ethics 55(2): 79-82. 